\title{
Relationship between Service Quality, Customer Loyalty and Customer Satisfaction
}

\section{Atif Mahmood*, Muhammad Luqman Tauheed Rana** and Sara Kanwal ${ }^{* * *}$}

\begin{abstract}
This study examined the influence of service quality on customer loyalty, and aimed to determine if this relationship was mediated by customer satisfaction. Data were gathered from customers of eight banks in Pakistan through an adapted self-administered questionnaire. Respondents were selected using convenience sampling. The distributed questionnaire was based on a modified SERVQUAL model.479 complete survey responses were returned out of a total of 700 distributed. The completed questionnaires were examined through descriptive statistics, regression analysis, and PROCESS technique (Hayes2013). Results revealed a significant effect of service quality on customer loyalty. Customer satisfaction was found to have a significant mediating effect on the relationship between service quality and customer loyalty. The outcomes of our study could be useful for policy-making in bank management, and future banking expansion. There is additional generalized benefit to having insight into customers' thinking regarding the banking sector.
\end{abstract}

Keywords: SERVQUAL, service quality, customer satisfaction, technology, customer loyalty

\section{JEL Classification: M19.}

\section{Introduction}

In most developed countries, the service sector, which includes the banking industry, plays an imperative role in economic growth and prosperity (Ostrom et al., 2010). Likewise, in Pakistan, banks are an important tool for economic development; these financial institutions are continuously expanding and offering a wide range of financial services, investment opportunities within and outside the country leading to

\footnotetext{
${ }^{*}$ Assistant Professor, Lahore Business School, University of Lahore, Pakistan.

${ }^{* *}$ PhD Scholar, COMSATS University, Lahore, Pakistan.

*** Lecturer, Institute of Business and Management, University of Engineering and Technology Lahore.
} 
further economic growth (Khalid \& Irshad, 2010). However, product quality is equally important for customer satisfaction. Customers have become more knowledgeable of required standards of quality and demand sufficient services. This is why, in order to achieve success, it is a necessity for every business to provide high quality services (Lee \& Lin, 2005). Service providers should also maintain a good relationship with their customers (Panda, 2003) as these relationships define customer satisfaction and loyalty with the organization (Joseph et al., 2005).

Numerous researchers have stated that service quality provided by an organization impacts its performance (Portela \& Thanassoulis, 2005), market share (Fisher, 2001), sales profit, (Duncan \&Elliot, 2002) and customer loyalty (Ehigie, 2006). Caruana (2002) has provided evidence that loyalty, satisfaction of customers, and quality of service are interrelated. Furthermore, emergence of technology in the service sector has increased customer expectation of service providers (Al-Eisa and Alhemoud, 2009). Thus, usage of adequate technology to deliver quality products to customers, and maintaining healthy links with customers is as important as any other feature for the survival of companies. Although literature is available on the topic of service quality, there still exists a gap in the research. Neither the direct effect of service quality on customer loyalty, nor the indirect effect via mediators has been fully explored within the framework of a developing country such as Pakistan.

Within the perspective of new age technology used in the banking industry in Pakistan, our research has two objectives. The primary aim is the prediction customer loyalty by service quality. Secondarily, it examines the mediation of customer satisfaction in quality of services and loyalty. Furthermore, according to disconfirmation theory of satisfaction (Oliver, 1977; 1980), a good business wants its customers neither dissatisfied nor delighted, but rather always satisfied. It is hard to provide banks with a single solution for customer satisfaction, but it is important that managers know where their customers stand on the three satisfaction levels, or stages: dissatisfaction stage, satisfaction stage, and delighted stage. They should also be aware of their competitors' challenges. This research provides an addition in the literature of services marketing and will help bank managers to understand their customers in an effective manner, set their strategies to compete in the market, and meet the expectations of customers in a developing country like Pakistan. 


\section{Review of Literature}

\subsection{Service Quality}

It is imperative for banks to plan their strategies in such a way that they can be competitive in a crowded market. This can be achieved if banks concentrate on high-quality service and an effective delivery process, as high-quality service increases satisfaction level among customers, further developing customer loyalty (Caruana, 2002). A service is defined as an offered, intangible performance (Kotler \& Keller, 2006). A service has various characteristics: incorporeal in nature, cannot be measured by any physical instrument, components are inseparable, and is variable as it cannot be the delivered in the same manner at different time periods (Ograjenšek, 2008).

Parasuraman et al (1988) have suggested different items to measure the quality of services. A few alterations have been made to this scale over time, and the measurement tool is known today as SERVQUAL. Its five dimensions are listed here:

1) Tangibles - Equipment and other components of physical existence.

2) Reliability - Delivery of committed services.

3) Responsiveness - Interest in customers' problems and quick delivery of services.

4) Assurance - Perception of courtesy, security, and guarantee of competence provided by employees.

5) Empathy - How firms and their employees demonstrate understanding of customers' needs.

\subsection{Customer Satisfaction}

Customer satisfaction develops when a customer compares the received value of a service to their expectations (Kotler et al., 2009). It is the overall judgment of a customer of any good or service (Woodruff, 1997), which helps (or hinders) service providers in maintaining strong relationships with their customers. Service quality is associated with customer satisfaction (Cronin et al., 2000), which is achieved when firms meet customers' needs and provide services that meet market standards (Gitomer, 1998). Customer satisfaction is significantly affected by service quality (Muyeed, 2012). 


\subsection{Customer Loyalty}

Customer loyalty manifest when customers are motivated to repurchase the service or product, or try to convince others to purchase the same service or product (Heskett et al., 1994). According to Duffy (2003), customer loyalty is a customer's emotional attachment to a brand. These emotional attachments leads the customers to purchase a brand repeatedly; as a result, firms receive financial benefit from loyal customers. Generally, banks aim to maximize profits, expand their business, and position themselves favorably among their competitors. Customer loyalty is a tool to aid with profit seeking, positioning, and expansion of goals (Hayes, 2008). Anderson \& Mittal (2000) confirmed the strong association of quality of services and customers' loyalty and this association was also confirmed by other studies (Oliva et al., 1992; Bloemer \& De Ruyter, 1999).

\subsection{Tangibility}

A combination of both incorporeal and tangible features of services/products quality can play a vital role in developing long haul association of banks and their valuable customers, and can increase the likelihood of customer retention (Zineldin, 2005). Organizations generally want their consumers to view them positively. This goal can be fulfilled more effectively if firms focus on the tangibility of their provided services (Swar \& Sahoo, 2012), which serves to garner the attention of customers (Ladhari et al., 2011). Similarly, banks can acquire the loyalty of their customers by providing the best tangible facilities (Jabnoun and AlTamimi, 2003). Disconfirmation theory (Oliver, 1977; 1980) postulates that tangibility is a dimension of service quality which facilitates the provision of better products and services to customers; based upon this, customers compare their expectations and perceptions related to the tangibility dimension of services. The difference between their expectations and their perceptions further affects satisfaction, which is followed by their loyalty. We posit that the tangibility dimension of service quality has a vital part to play in establishing satisfaction and loyalty. Therefore, hypotheses related to tangibility are:

H1: Tangibility is positively associated with customer satisfaction.

H2: Tangibility is positively linked to customer loyalty. 


\subsection{Reliability}

Ibáñezet al. (2006) have confirmed the significant association between reliability of services and satisfaction from these services. It is also observed in the literature that the relationship between customer satisfaction and service reliability becomes stronger when employees deal directly with customers (Muyeed, 2012). Similarly, a study of the banking sector in Malaysia found that reliability leads to develop loyal customers (Sureshchandar et al., 2003) and it is also have confirmed by Brown and Mitchell (1993). Disconfirmation theory (Oliver, 1977;1980) provides support for these studies and proposes that reliability of services helps the customers make comparisons between their perception of the firms' products/services and their expectations of those products/services. Satisfaction with services further creates loyalty with that firm. Therefore, the third and fourth hypotheses of this research are:

H3: Reliability is positively associated with customer satisfaction

H4: Reliability is positively linked to customer loyalty.

\subsection{Responsiveness}

In line with the disconfirmation theory presented by Oliver $(1977 ; 1980)$, numerous studies suggest that responsiveness positively affects customer satisfaction (Parasuraman et al., 1988; Sigala et al., 2006; Joseph et al., 2005). Customers respond positively when firm services meet their expectations (Diaz \& Ruiz, 2002). The positive alignment of expectations and perceptions results in customer satisfaction and eventually their loyalty. Likewise, responsiveness is utilized as a tool in creation of satisfaction and loyalty in customers (Glaveli et al., 2006). Responsiveness not only aids in developing loyalty in customers, but it builds long-term relationships with them (Ndubisi, 2006). Thus, the fifth and sixth hypotheses of our study are as follows:

H5: Responsiveness is positively associated with customer satisfaction.

H6: Responsiveness is positively linked to customer loyalty.

\subsection{Assurance}

As discussed above, service quality is constructed of three main pillars (reliability, responsiveness and tangibility) which significantly influence customer satisfaction (Parasuraman et al., 1988). Ndubisi (2006) 
confirmed that trustworthy employee behavior also leads to greater customer satisfaction. Bitner (1990) observed that loyalty of customers is strongly affected by the assurance about services. Muyeed (2012) argued that the loyalty of customers and assurance about services are more strongly associated than the other dimensions of service quality. Moreover, as described by disconfirmation theory (Oliver, 1977; 1980), the customers analyze whether or not the perceived service feature, such as assurance from employees, is consistent with customers' expectations. When customers feel that assurance received from the employees meets their expectations, they are satisfied, and consequently develop loyalty. Hence, the seventh and eighth hypotheses of this research are:

H7: Assurance is positively associated with customer satisfaction.

H8: Assurance is positively linked to customer loyalty.

\subsection{Empathy}

According to Iglesias \& Guillen (2004), customer satisfaction is greatly driven by empathy. Al-Marri et al. (2007) have also confirmed the link between empathy and customer satisfaction; they have verified that empathy serves as a tool to create long-term relationships between firm and customers. According to disconfirmation theory (Oliver, 1977; 1980), this occurs when customers find that firm employees provide individualized support and personal attention; customers' expectations are fulfilled and they become satisfied, improving the likelihood of becoming loyal to the firm. Similar results were presented by Jabnoun \& Al-Tamimi (2003), stating that in any service sector, customers cannot be loyal with the firm until and unless individual attention is given to the customers. Organizations can maintain a large customer base by providing each of them individual attention (Ford et al., 2005).With this in mind, the ninth and tenth hypotheses of our study are:

H9: Empathy is positively related with customer satisfaction.

H10: Empathy is positively associated with customer loyalty.

\subsection{Technology}

Developed technologies improve services and enhance the satisfaction of customers, ultimately leading to loyalty of customers (Surjadjaja et al., 2003). As discussed above, disconfirmation theory (Oliver, 1977; 1980) states that customers compare their expectation level 
with the delivery of service and develop their satisfaction or dissatisfaction based on the extent to which their perception of service quality matches their expectations; this satisfaction further establishes loyalty towards the firm. Technology can improve the delivery of services, making the customers delightful, and as a result they become loyal with the organization (Rafaeli et al., 2008). Therefore, the following eleventh and twelfth hypotheses have been developed:

H11: Technology is positively related with customer satisfaction.

H12: Technology is positively related with customer loyalty.

\subsection{Association of Satisfaction and Loyalty of Customers}

Customer satisfaction has a positive relationship with customer loyalty (Brimpong, 2008), as it ensures the retention of customers (Mosahab, et al., 2010). Muhammad et al. (2011) explained that loyalty of customers is significantly predicted by their satisfaction and the association of these factors is strong (Kumar et al., 2010). Correspondingly, the thirteenth hypothesis is:

H13: Customer satisfaction predicts customer loyalty positively.

\subsection{Mediation of Customers' Satisfaction}

The mediation by customers' satisfaction was purported in the disconfirmation theory proposed by Oliver (1977; 1980) in the relationship between service quality and customer loyalty. According to this theory, individuals face positive disconfirmation when the services they receive exceed their expectations, and customer satisfaction is high. Similarly, individuals face negative disconfirmation when the services they receive are below expectation, and as a result, their satisfaction with the service is low. The literature provides support for the idea that customer satisfaction derived by service quality can mediate the effect of service quality on customer loyalty. For instance, it was suggested that in the Bangladeshi telecommunication industry the association of quality and loyalty for services is significantly mediated by the satisfaction of their customers (Akbar \& Parvez, 2009). Likewise, Ismail et al. (2006) reported that the impact of reliability (a dimension of service quality) on customer loyalty is partially mediated by customer satisfaction in a Malaysian context. Kheng et al. (2010) found a strong mediating effect of satisfaction between the dimensions of services quality and loyalty of 
customers in the banking sector. Kumar et al. (2010) reported that customer loyalty is indirectly affected by service quality through customer satisfaction. Additionally, a partial mediation was found in relation of quality and loyalty by satisfaction is services' context (Osman and Sentosa, 2014). Considering these studies, we develop the remaining hypotheses in this way:

H14 (a): Association of tangibility and loyalty of customers is positively and significantly mediated by customers' satisfaction.

H14 (b): Association of reliability and loyalty of customers is positively and significantly mediated by customers' satisfaction.

H14 (c): Association of responsiveness and loyalty of customers is positively and significantly mediated by customers' satisfaction.

H14 (d): Association of assurance and loyalty of customers is positively and significantly mediated by customers' satisfaction.

H14 (e): Association of empathy and loyalty of customers is positively and significantly mediated by customers' satisfaction.

H14 (f): Association of technology and loyalty of customers is positively and significantly mediated by customers' satisfaction.

\subsection{Theoretical Framework}

The theoretical framework for this study has been adapted from multiple studies (Parasuraman et al., 1988; Agus et al., 2007; HarridgeMarch et al., 2008; Ganguli \& Roy, 2011). It is presented in Figure 1.

Figure 1: Service Quality, Customer Satisfaction, and Customer Loyalty

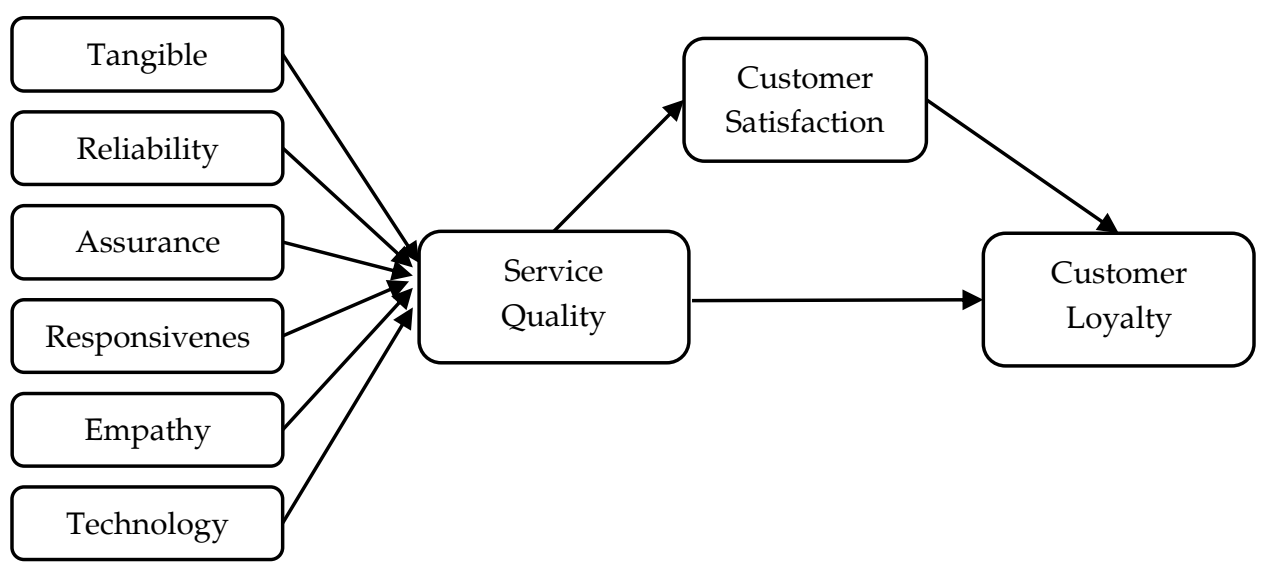




\section{Method}

\subsection{Sample and Procedure}

The aim of this study was to examine the influence of service quality on the development of customer loyalty, and the mediating effect of customer satisfaction on this relationship. To accomplish this, convenience sampling was employed, where data were collected from eight top-rated Pakistani banks, through self-administered questionnaires. In keeping with ethical considerations, respondents were contacted with the permission of the banks' management, and informants were invited to participate of their own will. To avoid bias, all questionnaires were enclosed with a cover letter which assured bank clients of anonymity during analysis and reporting. Data were collected within approximately 1 month. Out of total 700 distributed questionnaires, 479 responses were completed and returned.

\subsection{Measurements}

A five-point Likert scale ranging from 1 = "Strongly disagree" to $5=$ "Strongly agree" was used to measure all the questionnaire items. The survey questionnaire comprised 33 items and was divided into four parts. The first part included six dimensions of service quality, five of which were adapted from previous studies (Parasuraman et al., 1988; Wong et al., 2008), and a new dimension, Technology, added to the theoretical framework (Ganguli and Roy, 2011). The second and third parts of the questionnaire, adapted from Mohsan et al. (2011), were related to customer satisfaction and customer loyalty respectively. The final part of questionnaire collected demographic information from respondents.

\section{Results}

Prior to hypotheses testing, the data were checked for autocorrelation, multi-collinearity, linearity, heteroskedasticity, normality, and outliers. Results confirmed that the data were linear, normally distributed, and free of multi-collinearity issues, heteroskedasticity, and outliers, which could alter the results of the regression. Next, the instrument was checked for validity and reliability: Cronbach's alpha coefficients were computed for internal consistency of all variables used in research questionnaire. Cronbach's alpha values are given as follow: tangibility $(\alpha=.71)$, reliability $(\alpha=.74)$, responsiveness $(\alpha=.70)$, assurance $(\alpha=.76)$, empathy $(\alpha=.80)$, technology $(\alpha=.78)$, customer satisfaction $(\alpha=$ $.78)$, and customer loyalty $(\alpha=.82)$. These values were found to be 
satisfactory, as the threshold point of Cronbach's alpha is considered as .70 (DeVellis, 2003; 2012). All values in our study exceeded this threshold, demonstrating that all items have high internal consistency.

\subsection{Respondents Profile}

As stated earlier, the final part of the questionnaire collected demographic information (age, gender, qualification, and occupation). Table 1 depicts details of respondent demographic characteristics. Respondent data show that most of the sampled individual customers of banks are male undergraduate students aged between 18 and 27 years.

Table 1: Respondents Profile

\begin{tabular}{llcc}
\hline Variables & Frequency & $\begin{array}{c}\text { Percentage } \\
\mathbf{( N = 4 7 9 )}\end{array}$ & $\begin{array}{c}\text { (N=479) } \\
\text { Gender }\end{array}$ \\
Age & Female & 301.0 & 62.8 \\
& $18-27$ & 178.0 & 37.2 \\
& $28-37$ & 335.0 & 69.9 \\
& $38-47$ & 66.0 & 13.8 \\
Education & $48-55$ & 26.0 & 5.4 \\
& More than 55 & 28.0 & 5.8 \\
& Undergraduate & 24.0 & 5.0 \\
& Graduate & 177.0 & 37.0 \\
Occupation & Post graduate & 105.0 & 21.9 \\
& Others & 194.0 & 40.5 \\
& Salaried & 3.0 & 0.6 \\
& Self employed & 185.0 & 38.6 \\
& Student & 24.0 & 5.0 \\
& Others & 268.0 & 55.9 \\
& & 2.0 & 0.4 \\
\hline
\end{tabular}

\subsection{Descriptive Analysis}

Descriptive statistics are presented in Table 2.

Table 2: Descriptive Statistics

\begin{tabular}{lccc}
\hline Variable & Mean & St Deviation & Variance \\
\hline Tangibility & 3.3933 & 0.71042 & 0.505 \\
Reliability & 3.8544 & 0.72631 & 0.528 \\
Responsiveness & 3.7655 & 0.80067 & 0.641 \\
Assurance & 3.8773 & 0.81724 & 0.668 \\
Empathy & 3.8075 & 0.76401 & 0.584 \\
Technology & 3.9118 & 0.77329 & 0.598 \\
Customer satisfaction & 3.8030 & 0.68337 & 0.467 \\
Customer loyalty & 3.8058 & 0.81941 & 0.671 \\
\hline $\mathbf{N = 4 7 9}$ & & & \\
\hline
\end{tabular}




\subsection{Hypotheses Testing}

4.3.1. Impact of service quality on customer satisfaction and loyalty

The hypothesized direct relationships in the theoretical framework have been tested through regression analysis and the results of all proposed relationships are provided in Table 3. Overall, the regression statistics depict that all dimensions of service quality have a significant positive and moderate to strong impact on customer satisfaction and loyalty. These results provide strong evidence in favor of H1 through H13. For instance, empathy is shown to have strong positive influence on customer satisfaction $(r=0.72, p<.05)$. Technology has a moderate impact on customer satisfaction $(r=0.640, p<.05)$ and on customer loyalty $(r=.59, p<.05)$.

Reliability has a relatively greater effect on customer loyalty. The tested hypotheses state that if quality of service is high for each dimension incorporated in the service by a bank's employees in Pakistan, then consumer satisfaction with that specific bank will be high. Similarly, when service quality provided by bank employees is enhanced, the customers are more loyal. Thus, hypotheses H1 to H12 are accepted at a significant level $(p<.00)$.

\subsubsection{Effect of satisfaction of customers on loyalty of customers}

Before testing the data for a mediating effect of customer satisfaction, we analyzed its direct impact on customer loyalty. Regression results are given in Table 3, showing that customer satisfaction with service is a significant predictor of customer loyalty $(r=$ $.78, p<.01)$. It can be deduced that when customers find banking service satisfactory, they also tend to engage those services again. Repeated engagement is likely due to the loyalty that a customer may develop for a specific product or service. Therefore, H13 (customer satisfaction affects customer loyalty positively and significantly) is accepted. 
Table 3: Direct effects

\begin{tabular}{|c|c|c|c|c|}
\hline Relationship (Direct effects) & $\begin{array}{l}\text { Co- } \\
\text { efficient }\end{array}$ & S.E & Sig & $\begin{array}{l}\text { Hypotheses } \\
\text { support }\end{array}$ \\
\hline $\begin{array}{l}\text { H1:Tangibility } \rightarrow \text { customer } \\
\text { satisfaction }\end{array}$ & 0.694 & 0.127 & 0.000 & Yes \\
\hline H2:Tangibility $\rightarrow$ customer loyalty & 0.608 & 0.042 & 0.000 & Yes \\
\hline H3:Reliability $\rightarrow$ customer satisfaction & 0.681 & 0.032 & 0.000 & Yes \\
\hline H4:Reliability $\rightarrow$ customer loyalty & 0.651 & 0.039 & 0.000 & Yes \\
\hline $\begin{array}{l}\text { H5:Responsiveness } \rightarrow \text { customer } \\
\text { satisfaction }\end{array}$ & 0.657 & 0.030 & 0.000 & Yes \\
\hline $\begin{array}{l}\text { H6:Responsiveness } \rightarrow \text { customer } \\
\text { loyalty }\end{array}$ & 0.622 & 0.037 & 0.000 & Yes \\
\hline H7:Assurance $\rightarrow$ customer satisfaction & 0.697 & 0.027 & 0.000 & Yes \\
\hline H8:Assurance $\rightarrow$ customer loyalty & 0.641 & 0.035 & 0.000 & Yes \\
\hline H9:Empathy $\rightarrow$ customer satisfaction & 0.728 & 0.028 & 0.000 & Yes \\
\hline H10:Empathy $\rightarrow$ customer loyalty & 0.612 & 0.037 & 0.000 & Yes \\
\hline $\begin{array}{l}\text { H11:Technology } \rightarrow \text { customer } \\
\text { satisfaction }\end{array}$ & 0.640 & 0.031 & 0.000 & Yes \\
\hline H12:Technology $\rightarrow$ customer loyalty & 0.594 & 0.039 & 0.000 & Yes \\
\hline $\begin{array}{l}\text { H13:Customer satisfaction } \\
\rightarrow \text { customer loyalty }\end{array}$ & 0.781 & 0.034 & 0.000 & Yes \\
\hline
\end{tabular}

\subsubsection{Mediation of Customer Satisfaction}

Next, we addressed whether customer satisfaction with product/service can have a mediating effect which we measured using the PROCESS technique by Hayes $(2012 ; 2013)$. The results, given in Table 4 , demonstrate a mediating effect of customer satisfaction on the relationship between tangibility and $\operatorname{loyalty}(r=.10)$. The mediating effect of customer satisfaction was also demonstrated on the relationships between reliability and loyalty $(r=.08)$, assurance and loyalty $(r=.10)$, empathy and loyalty $(r=.15)$, as well as technology and loyalty $(r=$ .09).LLCI and ULCI for all relationships except responsiveness and loyalty have the same sign, which provides evidence to accept these hypotheses. However, results show that signs of LLCI and ULCI are not same in the case of the responsiveness and loyalty relationship. Therefore this hypothesis $(\mathrm{H} 14 \mathrm{c})$ was not accepted. The relationship of five service quality dimensions with loyalty of customers is positively mediated by customer satisfaction. Moreover, these findings verify all parts of hypothesis H14 (H14a to H14f) except H14c, which state that when 
responsiveness is improved in banks, customers are satisfied with this progression, and in turn customer satisfaction level boosts loyalty with the bank's product/service.

\section{Table 4: Indirect effects}

\begin{tabular}{lccccc}
\hline Hypothesis & Effect & Boot SE & LLCI & ULCI & $\begin{array}{c}\text { Hypotheses } \\
\text { support }\end{array}$ \\
\hline H14a: & 0.1023 & 0.0297 & 0.0464 & 0.1647 & Yes \\
\hline H14b: & 0.0811 & 0.0269 & 0.0317 & 0.1403 & Yes \\
\hline H14c: & 0.0041 & 0.0292 & -0.0618 & 0.0572 & No \\
\hline H14d: & 0.1009 & 0.0287 & 0.0540 & 0.1674 & Yes \\
\hline H14e: & 0.1446 & 0.0398 & 0.0274 & 0.2264 & Yes \\
\hline H14f: & 0.0848 & 0.0328 & 0.0301 & 0.1697 & Yes \\
\hline
\end{tabular}

\subsection{Discussion}

The findings of this research provide strong evidence that all dimensions of service quality significantly enhance customer loyalty. That is, tangibility, reliability, responsiveness, assurance, empathy, and technology within the processes of the service quality model increase customer loyalty. This result confirms the study by Sureshchandar et al. (2003) which encouraged business organizations (specifically banks) to focus on these dimensions in order to create loyalty. Furthermore, the five dimensions of service quality (tangibility, reliability, assurance, empathy, and technology) affect loyalty via customer satisfaction. These results are consistent with the findings of previous research (Glaveli et al., 2006; Ndubisi, 2006) that stated when these traits of service quality are incorporated by employees; they directly enhance consumer loyalty and satisfaction, which leads to their loyalty towards any bank. When customers are provided assurance, reliability, and tangibility of service from a bank's employees, the customer experience and association with the bank improves, and good experiences lead to their satisfaction and loyalty. Likewise, the significant link between empathy, customer loyalty and customer satisfaction is also evidenced in this research, in accordance with previous research (Ndubisi, 2006).

Similarly, advancement of technology influences customer satisfaction and loyalty. These outcomes are consistent with past studies (Ganguli and Roy, 2011; Ehigie, 2006). However, although responsiveness directly increases customer loyalty, customer satisfaction does not 
mediate the relationship between responsiveness and customer loyalty. When addressing consumer queries regarding products or processes, instant response to consumers and better solutions to problems can increase customer loyalty. But customer satisfaction through responsiveness does not affect their loyalty. This result is contradictory to the findings of Glaveli et al. (2006).It is imperative that banks prioritize the design of policies and processes of service provision, addressing consumer needs for service quality. This may contribute to higher levels of customer satisfaction and customer loyalty.

\section{Conclusions}

Previous research indicates that there is direct influence of service quality on customer loyalty. However, a gap still exists in literature that analyzes different mediation mechanisms of this relationship. Based on expectation disconfirmation theory, the purpose of this research was to determine if customer satisfaction mediates the relationship between service quality and customer loyalty. This study provided the evidence for this mediation and found that customer satisfaction strongly mediates the link between customer loyalty and the five service quality dimensions of tangibility, reliability, assurance, empathy, and technology in the banking industry of Pakistan. We found that responsiveness only directly affects customer loyalty, but not via the mediation of customer satisfaction.

\subsection{Directions for Further Work}

Outcomes of this work can be understood within the scope of certain limitations. As our research was carried out in Pakistan, a developing country; the results may be different throughout other areas of world. The respondents were selected through convenience sampling; random sampling may be employed in future research work. The research design for data collection in our study was cross-sectional; longitudinal design can be utilized in future research. Outcomes may not apply for the customers of other industries outside of the banking sector; a study on other industries may be conducted to verify this direct relationship and mediating factors. 


\section{References}

Agus, A., Barker, S., \& Kandampully, J. (2007). An exploratory study of service quality in the Malaysian public service sector. International Journal of Quality \& Reliability Management, 24(2), 177-190.

Akbar, M. M., \& Parvez, N. (2009). Impact of service quality, trust, and customer satisfaction on customers loyalty. ABAC Journal, 29(1).

Al-Eisa, A. S., \& Alhemoud, A. M. (2009). Using a multiple-attribute approach for measuring customer satisfaction with retail banking services in Kuwait. International Journal of Bank Marketing, 27(4), 294-314.

Al-Marri, K., Moneim M. Baheeg Ahmed, A., \& Zairi, M. (2007). Excellence in service: An empirical study of the UAE banking sector. International Journal of Quality $\mathcal{E}$ Reliability Management, 24(2), 164-176.

Anderson, E. W., \& Mittal, V. (2000). Strengthening the satisfaction-profit chain. Journal of Service Research, 3(2), 107-120.

Bitner, M. J. (1990). Evaluating service encounters: The effects of physical surroundings and employee responses. The Journal of Marketing, 69-82.

Bloemer, J., \& De Ruyter, K. (1999). Customer loyalty in high and low involvement service settings: The moderating impact of positive emotions. Journal of Marketing Management, 15(4), 315-330.

Brimpong, M. A. (2008). The effect of customer satisfaction on loyalty: A case study of First Allied Savings and Loans Ltd (Doctoral Dissertation). Retrieved from http://ir.knust.edu.gh/bitstream/123456789/683 /1/MALCOLM A. BRIMPONG.pdf

Brown, K. A., \& Mitchell, T. R. (1993). Organizational obstacles: Links with financial performance, customer satisfaction, and job satisfaction in a service environment. Human Relations, 46(6), 725-757.

Caruana, A. (2002). Service loyalty: The effects of service quality and the mediating role of customer satisfaction. European Journal of Marketing, 36(7/8), 811-828. 
Cronin, J. J., Brady, M. K., \& Hult, G. T. M. (2000). Assessing the effects of quality, value, and customer satisfaction on consumer behavioral intentions in service environments. Journal of Retailing, 76(2), 193-218.

DeVellis, R. F. (2003). Scale development: Theory and applications (2nd ed.): Thousand Oaks, CA: Sage Publications, Inc.

DeVellis, R. F. (2012). Scale development: Theory and applications (Vol. 26): Sage publications.

Duffy, D. L. (2003). Internal and external factors which affect customer loyalty. Journal of Consumer Marketing, 20(5), 480-485.

Duncan, E., \& Elliott, G. (2002). Customer service quality and financial performance among Australian retail financial institutions. Journal of Financial Services Marketing, 7(1), 25-41.

Fisher, A. (2001). Winning the battle for customers. Journal of Financial Services Marketing, 6(1), 77-83.

Ford, J. B., Malhotra, N. K., Ulgado, F. M., Agarwal, J., Shainesh, G., \& $\mathrm{Wu}, \mathrm{L}$. (2005). Dimensions of service quality in developed and developing economies: Multi-country cross-cultural comparisons. International Marketing Review, 22(3), 256-278.

Gitomer, J. (1998). Customer satisfaction is worthless, customer loyalty is priceless: How to make them love you, keep you coming back, and tell everyone they know. Texas: Bard Press.

Harridge-March, S., Wong, D. H., Rexha, N., \& Phau, I. (2008). Reexamining traditional service quality in an e-banking era. International Journal of Bank Marketing, 26(7), 526-545.

Hayes, B. E. (2008). The true test of loyalty. Quality Progress, 41(6), 20-26.

Hayes, A. F. (2013). Introduction to mediation, moderation, and conditional process analysis:A regression-based approach. New York, NY: Guilford. 
Hayes, A. F. (2012). PROCESS: A versatile computational tool for observed variable mediation, moderation, and conditional process modeling [White paper]. Retrieved from http://www.personal.psu.edu/jxb14/M554/articles/process2012 .pdf, January, 2014.

Heskett, J. L., \& Schlesinger, L. (1994). Putting the service-profit chain to work. Harvard Business Review, 72(2), 164-174.

Ibáñez, V. A., Hartmann, P., \& Calvo, P. Z. (2006). Antecedents of customer loyalty in residential energy markets: Service quality, satisfaction, trust, and switching costs. The Service Industries Journal, 26(6), 633-650.

Ismail, I., Haron, H., Nasir Ibrahim, D., \& Mohd Isa, S. (2006). Service quality, client satisfaction, and loyalty towards audit firms: Perceptions of Malaysian public listed companies. Managerial Auditing Journal, 21(7), 738-756.

Jabnoun, N., \& Hassan Al-Tamimi, H. A. (2003). Measuring perceived service quality at UAE commercial banks. International Journal of Quality E Reliability Management, 20(4), 458-472.

Joseph, M., Sekhon, Y., Stone, G., \& Tinson, J. (2005). An exploratory study on the use of banking technology in the UK: A ranking of importance of selected technology on consumer perception of service delivery performance. International Journal of Bank Marketing, 23(5), 397-413.

Khalid, S., \& Irshad, M. (2010). Job satisfaction among bank employees in Punjab, Pakistan: A comparative study. European Journal of Social Sciences, 17(4), 570-577.

Kheng, L. L., Mahamad, O., Ramayah, T., \& Mosahab, R. (2010). The impact of service quality on customer loyalty: A study of banks in Penang, Malaysia. International Journal of Marketing Studies, 2(2), p57.

Kotler, P., \& Keller, K. (2006). Marketing Management (pp. 402): New Delhi, India: Prentice-Hall. 
Kotler, P., Keller, K. L., Koshy, A., \& Jha, M. (2009). Marketing management: A SouthAsian perspective (13th ed.): New Delhi, DL: Pearson Prentice Hall.

Kumar, V., Aksoy, L., Donkers, B., Venkatesan, R., Wiesel, T., \& Tillmanns, S. (2010). Undervalued or overvalued customers: Capturing total customer engagement value. Journal of Service Research, 13(3), 297-310.

Ladhari, R., Ladhari, I., \& Morales, M. (2011). Bank service quality: Comparing Canadian and Tunisian customer perceptions. International Journal of Bank Marketing, 29(3), 224-246.

Lee, G.-G., \& Lin, H.-F. (2005). Customer perceptions of e-service quality in online shopping. International Journal of Retail $\mathcal{E}$ Distribution Management, 33(2), 161-176.

Ganguli, S., \& Roy, S. K. (2011). Generic technology-based service quality dimensions in banking: Impact on customer satisfaction and loyalty. International Journal of Bank Marketing, 29(2), 168-189.

Mohsan, F., Nawaz, M. M., Khan, M. S., Shaukat, Z., \& Aslam, N. (2011). Impact of customer satisfaction on customer loyalty and intentions to switch: Evidence from banking sector of Pakistan. International Journal of Business and Social Science, 2(16), 230-245.

Mosahab, R., Mahamad, O., \& Ramayah, T. (2010). Service quality, customer satisfaction and loyalty: A test of mediation. International Business Research, 3(4), 72-80.

Muyeed, M. A. (2012). Customer perception on service quality in retail banking in developing countries: A case study. International Journal of Marketing Studies, 4(1), 116.

Ndubisi, N. O. (2006). A structural equation modelling of the antecedents of relationship quality in the Malaysia banking sector. Journal of Financial Services Marketing, 11(2), 131-141.

Ograjenšek, I. (2008). Service quality. Statistical Practice in Business and Industry, 117-136. 
Oliva, T. A., Oliver, R. L., \& MacMillan, I. C. (1992). A catastrophe model for developing service satisfaction strategies. the Journal of Marketing, 83-95.

Oliver, R. L., (1977), Effect of expectation and disconfirmation on post exposure product evaluation: An alternative interpretation, Journal of Applied Psychology, 62 (4), 480- 486.

Oliver, R. L., (1980), A cognitive model of the antecedents and consequences of satisfaction decisions. Journal of Marketing Research, 17(4), 460-469.

Osayawe Ehigie, B. (2006). Correlates of customer loyalty to their bank: Acase study in Nigeria. International Journal of Bank Marketing, 24(7), 494-508.

Osman, Z., Sentosa, I., (2014), Influence of customer satisfaction on service quality and customer loyalty relationship in Malaysian commercial banking industry. International Journal of Economics, Finance, and Management, 3(2), 115-120

Ostrom, A. L., Bitner, M. J., Brown, S. W., Burkhard, K. A., Goul, M., Smith-Daniels, V., ... \& Rabinovich, E. (2010). Moving forward and making a difference: research priorities for the science of service. Journal of service research, 13(1), 4-36.

Panda, T. K. (2003). Creating customer life time value through effective CRM in financial services industry. Journal of Services Research, 2(2), 157-171.

Parasuraman, A., Zeithaml, V. A., \& Berry, L. L. (1988). SERVQUAL- a multiple-item scale for measuring consumer perceptions of service quality. Journal of Retailing, 64(1), 12-40.

Pedraja Iglesias, M., \& Jesus Yagüe Guillén, M. (2004). Perceived quality and price: Their impact on the satisfaction of restaurant customers. International Journal of Contemporary Hospitality Management, 16(6), 373-379.

Portela, M. C. A. S., \& Thanassoulis, E. (2005). Profitability of a sample of Portuguese bank branches and its decomposition into technical and allocative components. European Journal of Operational Research, 162(3), 850-866. 
Rafaeli, A., Ziklik, L., \& Doucet, L. (2008). The impact of call center employees' customer orientation behaviors on service quality. Journal of Service Research, 10(3), 239-255.

Sigala, M., Christou, E., Glaveli, N., Petridou, E., Liassides, C., \& Spathis, C. (2006). Bank service quality: Evidence from five Balkan countries. Managing Service Quality: An International Journal, 16(4), 380-394.

Sureshchandar, G., Rajendran, C., \& Anantharaman, R. (2003). Customer perceptions of service quality in the banking sector of a developing economy: Acritical analysis. International Journal of Bank Marketing, 21(5), 233-242.

Surjadjaja, H., Ghosh, S., \& Antony, J. (2003). Determining and assessing the determinants of e-service operations. Managing Service Quality: An International Journal, 13(1), 39-53.

Swar, B. N., \& Sahoo, P. K. (2012). Public, private, and foreign banks. Journal of Indian Management, 9(3), 43-51.

Woodruff, R. B. (1997). Customer value: The next source for competitive advantage. Journal of the Academy of Marketing Science, 25(2), 139-153.

Zineldin, M. (2005). Quality and customer relationship management (CRM) as competitive strategy in the Swedish banking industry. The TQM Magazine, 17(4), 329-344. 